\title{
Whole genome analysis of the koa wilt pathogen (Fusarium oxysporum f. sp. koae) and the development of molecular tools for early detection and monitoring
}

John T. Dobbs' ${ }^{1}$, Mee-Sook Kim², Nicklos S. Dudley ${ }^{3}$, Ned B. Klopfenstein ${ }^{4}$, Aileen Yeh³ ${ }^{3}$ Robert D. Hauff ${ }^{5}$, Tyler C. Jones ${ }^{3}$, R. Kasten Dumroese ${ }^{4}$, Philip G. Cannon ${ }^{6}$ and Jane E. Stewart ${ }^{1 *}$

\begin{abstract}
Background: Development and application of DNA-based methods to distinguish highly virulent isolates of Fusarium oxysporum f. sp. koae [Fo koae; cause of koa wilt disease on Acacia koa (koa)] will help disease management through early detection, enhanced monitoring, and improved disease resistance-breeding programs.

Results: This study presents whole genome analyses of one highly virulent Fo koae isolate and one nonpathogenic $F$. oxysporum (Fo) isolate. These analyses allowed for the identification of putative lineage-specific DNA and predicted genes necessary for disease development on koa. Using putative chromosomes and predicted gene comparisons, Fo koae-exclusive, virulence genes were identified. The putative lineage-specific DNA included identified genes encoding products secreted in xylem (e. g., $S I X 1$ and $S I X 6$ ) that may be necessary for disease development on koa. Unique genes from Fo koae were used to develop pathogen-specific PCR primers. These diagnostic primers allowed target amplification in the characterized highly virulent Fo koae isolates but did not allow product amplification in low-virulence or non-pathogenic isolates of Fo. Thus, primers developed in this study will be useful for early detection and monitoring of highly virulent strains of Fo koae. Isolate verification is also important for disease resistance-breeding programs that require a diverse set of highly virulent Fo koae isolates for their disease-screening assays to develop disease-resistant koa.

Conclusions: These results provide the framework for understanding the pathogen genes necessary for koa wilt disease and the genetic variation of Fo koae populations across the Hawaiian Islands.
\end{abstract}

Keywords: Fusarium oxysporum, Lineage-specific DNA, Virulence genes, PCR primer, Haplotypes, Acacia koa

\footnotetext{
* Correspondence: jane.stewart@colostate.edu

'Colorado State University, Department of Agricultural Biology, 1177 Campus Delivery, Fort Collins, CO 80523, USA

Full list of author information is available at the end of the article
}

C C The Author(s). 2020 Open Access This article is licensed under a Creative Commons Attribution 4.0 International License, which permits use, sharing, adaptation, distribution and reproduction in any medium or format, as long as you give appropriate credit to the original author(s) and the source, provide a link to the Creative Commons licence, and indicate if changes were made. The images or other third party material in this article are included in the article's Creative Commons. licence, unless indicated otherwise in a credit line to the material. If material is not included in the article's Creative Commons licence and your intended use is not permitted by statutory regulation or exceeds the permitted use, you will need to obtain permission directly from the copyright holder. To view a copy of this licence, visit http://creativecommons.org/licenses/by/4.0/. The Creative Commons Public Domain Dedication waiver (http://creativecommons.org/publicdomain/zero/1.0/) applies to the data made available in this article, unless otherwise stated in a credit line to the data. 


\section{Background}

Intraspecific genomic comparisons between pathogenic and non-pathogenic fungal isolates can elucidate key factors required for pathogenicity in plant hosts $[1,2]$. These factors include unique genes that are not only vital for the pathogen to cause disease, but can also provide tools to differentiate pathogens and non-pathogens for detection and monitoring. Variation in genome size, predicted effectors, and unique genome regions have been used previously to differentiate plant pathogens from saprophytic non-pathogens [3-5]. Just as the hosts exhibit variation in resistance, fungal pathogens (e.g., Fusarium oxysporum) also exhibit variation in virulence [6]. Previous analyses of F. oxysporum f. sp. lycopersici and $F$. oxysporum f. sp. radicis-cucumerinum chromosomes identified conditionally dispensable chromosomes containing virulence factors that could be transferred between compatible strains through heterokaryon formation [4, 7]. Other previous studies found that these virulence factors were encoded by diverse genes. Fusarium transcription factors and their corresponding virulence genes, such as those encoding proteins secreted in xylem $(S I X)$, were found to be essential for pathogenesis and high virulence in most $F$. oxysporum formae species [8-11]. Based on carbohydrate-active enzyme analysis, the copy number and types of plant cell wall-degrading enzymes have been found to be important for pathogenesis of $F$. oxysporum formae species in legumes [12]. In addition, phytotoxic secondary metabolites and associated transporters (i.e., fusaric acid, fumonisin B1, and beauvericin) have been identified as important for pathogenesis in the $F$. oxysporum f. sp. cubense [12, 13], and transposable elements (i.e., miniature impala elements) have been documented to enhance effector diversity [14-16]. These factors help distinguish pathogenicity and/or virulence in Fusaria and could also provide a basis for early detection of pathogens which would facilitate disease management programs through efforts to reduce pathogen spread to uninfested sites.

Fusarium oxysporum is a cosmopolitan, ascomycete fungus with observed functions that range from an innocuous soil saprophyte to a catastrophic plant pathogen in important agricultural crops and ecologically important tree species [17]. In addition to these diverse functions, $F$. oxysporum is also known to display high levels of hostspecificity. These highly host-specific pathogenic strains are classified into formae speciales (forma specialis singular) that exhibit high genomic plasticity, which has been attributed to effector profiles housed on one to many conditionally dispensable, lineage-specific accessory chromosomes, where the vast majority of genomic variation exists, in comparison to a set of shared "core" chromosomes containing essential genes for normal cellular function [16, 18-20]. These lineage-specific chromosome(s) house genes involved in virulence and/or evasion of plant host detection and have been described as repeat- and transposon-rich [1, 3]. Comparisons of these virulence genes through whole-genome analyses are useful for distinguishing pathogens from nonpathogens on the susceptible host of a specific $F$. oxysporum forma specialis [1]. In this study, we analyzed and compared the genomes of pathogenic and non-pathogenic F. oxysporum strains, which were both isolated from the roots of Acacia koa A. Gray (koa).

Gardner (1980) described Fusarium wilt disease in low- to mid-elevation, below $610 \mathrm{~m}(2000 \mathrm{ft})$, forests in the Hawaiian archipelago affecting koa, an endemic tree species $[21,22]$. Koa trees are ecologically, economically, and culturally valuable to Hawai'i. Koa is the second most abundant tree in Hawai'i's forests and many of Hawai'i's indigenous flora and fauna rely on koa for food and shelter [21]. Due to koa's importance to Hawai' $i$, efforts have been increased to reincorporate koa into lowland forests, where its populations have declined [23]. Currently, koa wilt disease [caused by F. oxysporum f. sp. koae (Fo koae)] represents the predominant threat to koa across its native range [24].

Management methods for koa wilt disease include fumigation and pesticides that are environmentally harmful and economically costly when used in forests and/or timber stands. As a result, current efforts are focused primarily on producing disease-resistant seedlings derived from seed collected from natural stands [23]. To find naturally occurring resistance to the pathogenic strains of the fungus (Fo koae), wild-collected seed is used for extensive disease resistance-screening assays in the greenhouse [25]. These screening trials are costly and require diverse pathogenic Fo koae strains to ensure that the disease resistance is robust in the selected germplasm. Consequently, these disease resistancescreening programs would greatly benefit from faster, more cost-effective strategies for screening pathogenic Fo koae isolates. This screening process is further complicated by considerations that pathogenic fungi can evolve quickly; much faster than their plant hosts $[1,26$, 27]. For this reason, new, genetically diverse strains of the pathogen must be continually incorporated in screening programs to help ensure that disease resistance remains stable against newly evolved or introduced strains of the pathogen in Hawai'i's forest and agricultural lands. Collecting, isolating, and characterizing pathogenic Fo koae isolates is an arduous and timeconsuming process that requires 3-month greenhouse virulence assays to confirm pathogenicity. Pathogenspecific, PCR primers would allow for rapid detection of pathogenic Fo koae strains, which would expedite collections of new pathogenic strains for disease resistancebreeding programs to meet the needs of growers and land managers for restoration and/or timber purposes. 
Objectives for this study were to 1) conduct and analyze whole genome sequences of one highly virulent Fo koae isolate and one non-pathogenic $F$. oxysporum $(F o)$ isolate both collected from koa; 2) identify virulence-associated genes with putative roles in koa wilt disease; 3) use the identified differences to develop Fo koae-specific PCR primers; and 4) test the robustness of the developed primers to identify highly virulent Fo koae isolates among uncharacterized $F$. oxysporum populations.

\section{Results}

\section{Whole genome sequencing and assembly}

To conduct whole genome comparisons, one pathogenic Fo koae isolate (44) and one non-pathogenic Fo isolate (170) were whole genome sequenced using Illumina TruSeq short-read sequencing $(150 \mathrm{bp})$. Libraries resulted in 397,390,528 reads with $1245 x$ coverage for pathogenic isolate Fo koae 44 and 385,805,256 reads with 1150x coverage for non-pathogenic isolate Fo 170. De novo assembly of both Fo koae 44 and Fo 170 identified genome sizes of 48 and $50 \mathrm{Mb}$, respectfully. The QUAST report metrics are shown in Table 1.

\section{Whole genome phylogenetic analysis}

A whole-genome maximum likelihood phylogeny was constructed to elucidate the evolutionary relationships of Fo koae 44 and Fo 170 compared with other Fusarium spp. and F. oxysporum formae speciales (Additional File 9). The phylogeny showed that both Fo koae 44 and Fo 170 grouped into a well-supported [Bootstrap $(B S)=100$ ] clade with other F. oxysporum formae speciales (Additional File 1). Interestingly, both isolates grouped into separate subclades with distinct $F$. oxysporum formae speciales, rather than grouping together (Additional File 1). Fo koae 44 clustered in a sub-clade $(\mathrm{BS}=100)$ that included $F$. oxysporum f. sp. cubense race 1 and Fo 170 clustered in a sub-clade (BS $=100)$ with F. oxysporum f. sp. gladioli. This result suggests that these isolates were indeed $F$. oxysporum and that Fo koae 44 and Fo 170 were sufficiently, genetically different to allow comparison for identifying lineage-specific DNA necessary for pathogenicity in koa.

Table 1 QUAST assembly statistics of the SPAdes de novo genome assembly of the pathogenic Fusarium oxysporum f. sp. koae 44 (Fo koae 44) and non-pathogenic F. oxysporum 170 (Fo 170) isolates

\begin{tabular}{lll}
\hline & Fo koae 44 & Fo $\mathbf{1 7 0}$ \\
\hline Genome size $(\mathrm{Mb})$ & $48,183,513$ & $50,628,816$ \\
Contig Number & 492 & 964 \\
Scaffold Number & 330 & 910 \\
N50 & 721,547 & 562,269 \\
GC\% & 47.5 & 47.2 \\
\hline
\end{tabular}

\section{Genomic analyses of Fo koae $\mathbf{4 4}$ and Fo 170}

Genomic sequences of Fo koae 44 and Fo 170 were aligned with reference genome sequences of a wellcharacterized F. oxysporum f. sp. lycopersici isolate (GenBank accession AAXH00000000.1) to identify regions of highest dissimilarity and identify lineage-specific DNA, with potential use for pathogen-specific primer development. Based on the reference genome, 11 putative "core" chromosomes shared synteny with Fo koae 44 and Fo 170. Putative lineage-specific DNA (LSX) was identified in each genome that did not map to the genome of $F$. oxysporum f. sp. lycopersici or show synteny with each other (Fo koae 44 and Fo 170) or genomes of other F. oxysporum formae speciales (Fig. 1a). Low-coverage sequences and non-Fusarium DNA were discarded to remove possible DNA contamination. The average nucleotide identity (ANIm) between Fo koae 44 and Fo 170 was $96.5 \%$. The remaining $3.5 \%$ genetic dissimilarity is largely due to the identified LSX. Further analyses comparing the putative chromosomes of Fo koae 44 and Fo 170 indicated that variants (SNPs and indels) were localized on specific chromosomes (LSX_44 and LSX_170) and at chromosome ends (Fig. 1b). Putative core chromosomes $1,2,4,5,7,8,9$, and 10 were the most similar with identified variants localized on chromosome ends, likely due to higher recombination observed at telomeres or assembly errors [20, 28]. Putative chromosomes 11, 12, 13, and LSX had the most variation (Fig. 1b). Analyses of the distribution of repeats and transposons determined that $F$. oxysporum transposable elements (e.g., Foxy, Skippy, Impala, Hop, Mariner, Hat, and Helitron) occurred on the LSX of both Fo koae 44 and Fo 170 [29]. The average core chromosome was comprised of 3 and $4 \%$ transposable elements and repeats in Fo koae 44 and $F_{o} 170$, respectively. In contrast, the transposable elements and repeats comprised 19 and 20\% of LSX for Fo koae 44 and Fo 170, respectively (Fig. 2a \& b). This localization of transposable elements provides evidence that differences within the LSX are likely attributable to one or more conditionally dispensable chromosome(s) in both Fo koae 44 and Fo 170.

\section{Genome annotation}

Using the Maker pipeline, 15,380 and 15,763 transcripts and corresponding proteins were predicted for Fo koae 44 and Fo 170, respectively, for use in identifying genes associated with pathogenicity in koa wilt disease. Using OrthoVenn2, 1760 non-orthologous proteins from 78 gene clusters and 1576 single genes, were identified as exclusive to Fo koae 44 when compared to Fo 170. In comparison, Fo 170 had 2123 exclusive non-orthologous proteins from 137 gene clusters and 1780 single genes. Fo koae 44 had enrichment of gene ontology (GO) terms for nucleic acid binding (Additional File 2), whereas Fo 


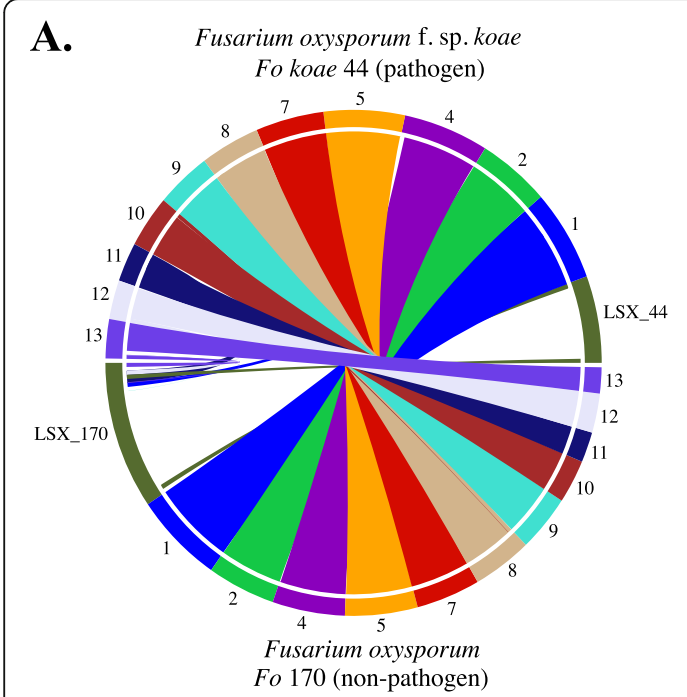

B.

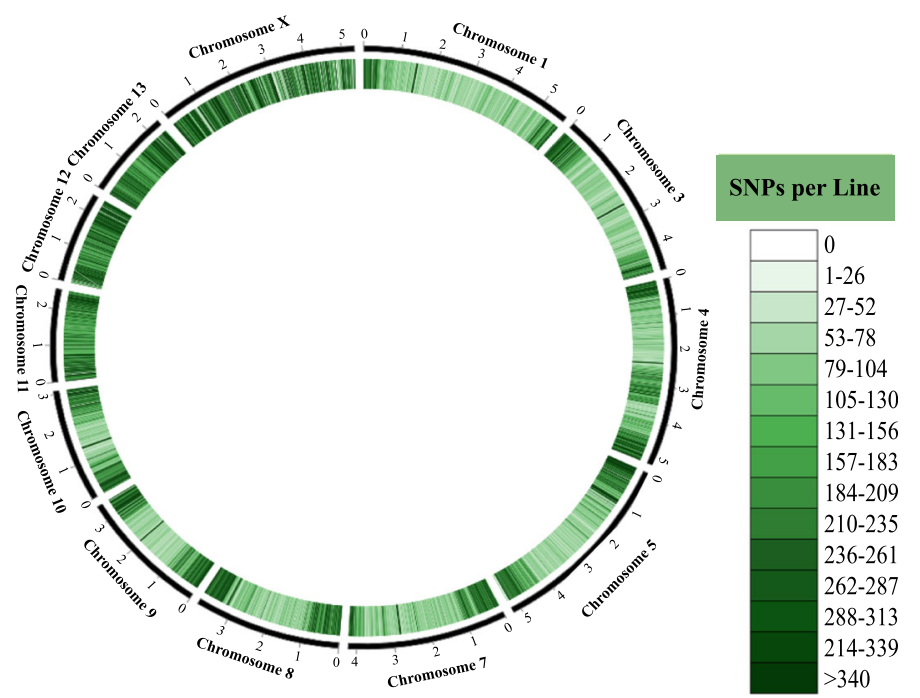

Fig. 1 a Synteny map showing synteny between each of 11 putative core chromosomes that were mapped to Fusarium oxysporum f. sp. lycopersici (reference strain). Most of the putative twelfth chromosome (putative lineage-specific DNA) denoted as LSX_44 for F. oxysporum f. sp. koae 44 (Fo koae 44) and LSX_170 for F. oxysporum 170 (Fo 170) does not show synteny between the pathogen and non-pathogen and did not map to the reference strain. This lack of synteny on the putative twelfth chromosome is indicative of lineage-specific DNA, putatively containing conditionally dispensable, accessory chromosomes. b Distribution of variants (single nucleotide polymorphisms, SNPs) comparing the putative chromosomes of the koa wilt pathogen Fo koae 44 and non-pathogenic Fo 170. Darker bars indicate more SNPs identified in that region. Putative chromosomes 11, 12, 13, and putative lineage-specific DNA (ChromosomeX; LSX) show the highest SNP densities

170 had enrichment of GO terms for GTP binding, regulation of transcription from RNA polymerase II promoter during meiosis, sporulation resulting in formation of a cellular spore, and regulation of DNA-template transcription (Additional File 3). The 13,500 protein clusters that were shared between Fo koae 44 and Fo 170 had no identified GO enrichment.

Using InterProScan, 16,429 and 16,487 putative protein family domains were identified in Fo koae 44 and Fo 170 , respectively. Of these putative proteins, 30 were unique to Fo koae 44, and 32 were unique to Fo 170. Interestingly, a sterigmatocystin biosynthesis gene was identified as unique in Fo koae 44. Of further note is that the genome of Fo 170 also encoded some proteins involved in pathogenesis, including oxidoreductases (i.e., monooxygenase) and putrescine biosynthesis.

Using the antiSMASH database, the genes associated with secondary metabolites were similar in both genomes of Fo koae 44 and Fo 170; however, variation did exist in gene copy number (Additional File 4). Nonribosomal peptide synthetases (NRPS), NRPS-like, and indoles had higher gene copy numbers for Fo koae 44. Fo 170 had two more copies of genes associated with the production of the Fusarium mycotoxin enniatin.

Similar results were observed from genes identified using the dbCAN2 database, except that two copies of a glycoside hydrolase, GH13_22 (characterized glucan synthase), were found in Fo koae 44, but not in Fo 170 [30]. In Fo 170, two gene copies encoding proteins
GH141 ( $\alpha$-L-fucosidase or xylanase), one copy encoding GH30 (endo- $\beta-1,4$-xylanase or $\beta$-glucosidase), and one copy encoding GH43_12 (a glycoside hydrolase involved in hydrolysis and/or rearrangement of glycosidic bonds; arabinosidase) were identified.

Using the PHI-base, shared virulence-associated genes that were identified in both Fo koae 44 and Fo 170 include the following: transport associated genes, such as the ATP-binding cassette (Gpabc1; PHI:258); effectors, such as the Ace1 (PHI:325) and Mocdip1 (PHI: 3213); Fusarium-specific transcription factors, such as the Ftf2 (PHI:5484) and the SIX gene (SGE1; PHI:3168); toxin detoxifying genes, such as the GzmetE (PHI:355) and Tom1 (PHI:438); a chitin synthase gene, CHS2 (PHI: 336); and a beta-1,3-glucanosyltransferase, GAS1 (PHI: 522). Nine virulence-associated genes were identified as unique to Fo koae 44. These genes encoded multiple $\mathrm{Fu}$ sarium transcription factors, mitogen-activated protein kinases, and ATP-binding cassette $(\mathrm{ABC})$ transporters. The SIX1 and SIX6 genes, were identified on the LSX of Fo koae 44, but were absent in the Fo 170 genome.

These Fo koae 44 virulence-associated genes showed sequence similarity to other $F$. oxysporum formae speciales (GenBank Accession numbers in Additional Files 10 and 5B). The SIX1 gene of Fo koae 44 showed highest sequence similarity with $F$. oxysporum $\mathrm{f}$. sp. fragariae $(85 \%)$ and the SIX6 gene showed highest sequence similarity to $F$. oxysporum f. sp. pisi (97\%) and F. oxysporum f. sp. сиситеrinum (97\%). There were seven virulence- 

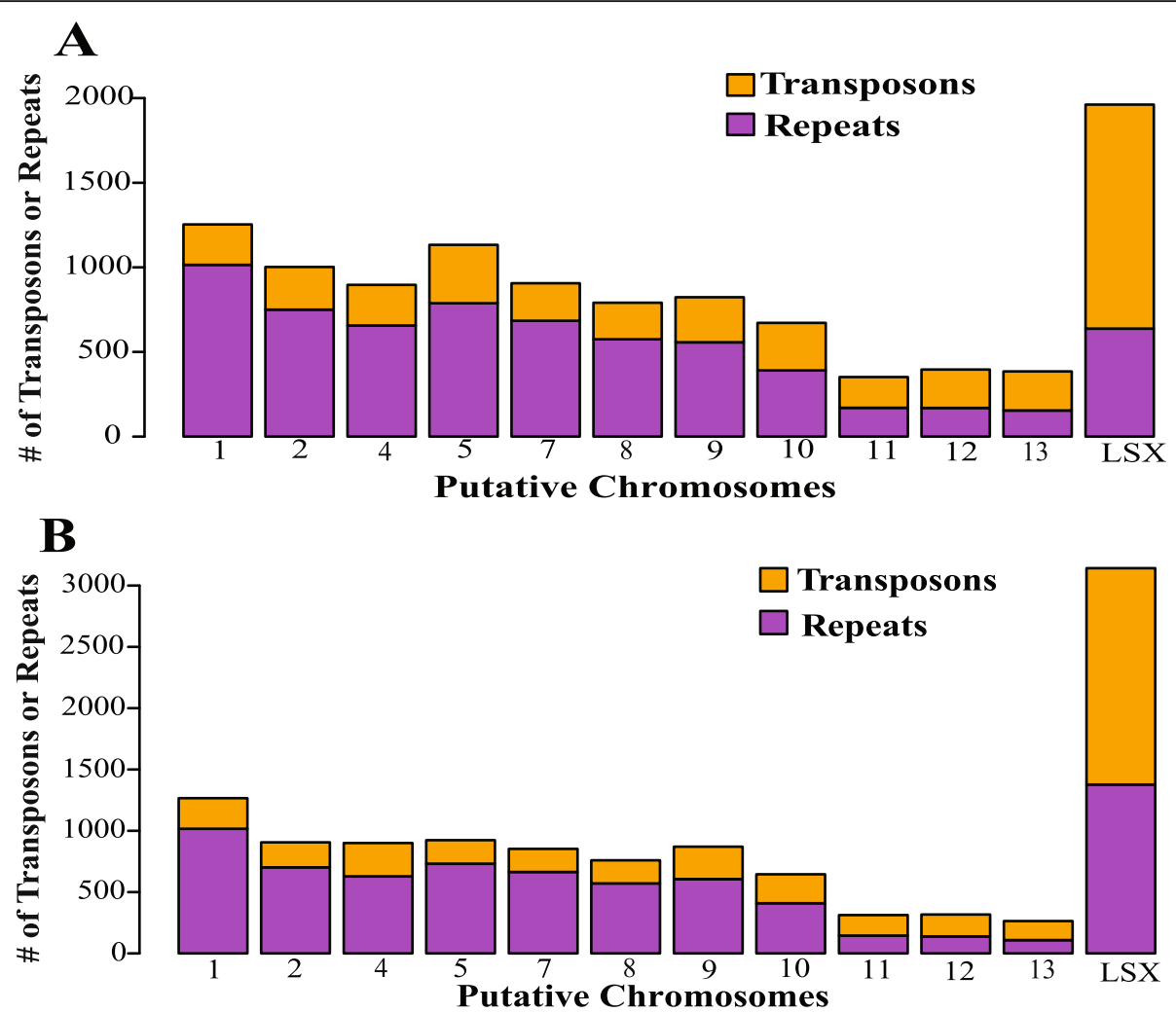

Fig. 2 a Distribution of transposons (orange bars) and repeats (purple bars) across the putative chromosomes and putative lineage-specific DNA (LSX) of Fusarium oxysporum f. sp. koae (Fo koae 44; koa wilt pathogen). b Distribution of transposons (orange bars) and repeats (purple bars) across the putative chromosomes LSX in Fusarium oxysporum (Fo 170). Majority of the transposons were identified in the LSX

associated genes identified as unique to Fo 170 that consisted of signaling proteins, ATP binding cassette transporter, and one of unknown function but related to developing root rot symptoms (PEP2).

\section{Fo koae-specific PCR primer development}

To increase the likelihood of developing a pathogenspecific primer, two approaches were used to classify genomic regions and genes unique to Fo koae 44 for PCR primer development. First, unique genomic regions, that may be non-coding DNA sequences, were identified in Fo koae 44. Second, predicted transcripts unique to Fo koae 44 were identified.

To identify unique genomic regions, Fo koae 44 chromosomes were aligned to chromosomes of Fo 170, other Fusarium spp., and F. oxysporum formae speciales obtained from GenBank (Additional File 9). Analysis of these alignments identified a total of 445 DNA sequences unique to Fo koae 44. Of these 445 DNA sequences, 33 had no BLAST hits to the NCBI database, and these 33 DNA sequences were selected for design of PCR primers.

To identify unique genes, Fo koae 44 and Fo 170 were analyzed using OrthoVenn2. One thousand seven hundred sixty-two predicted proteins were identified as exclusive to Fo koae 44. The corresponding transcripts were BLASTed to the NCBI database and 137 of these transcripts had no BLAST hits. These 137 transcripts were also selected for design of PCR primers.

Taken together, each of the 33 unique genomic DNA sequences and the 137 predicted transcripts (ca. 170 genome regions) were BLASTed against the chromosomes to determine which chromosome contained the selected sequence target for potential amplification. From these sequences, 3750 primers were developed in silico. Of those, 35 primer pairs had no non-target hits in silico through NCBI primer BLAST. These primers were tested on characterized pathogenic Fo koae isolates and non-pathogenic F. oxysporum (Table 2), F. commune (FO21 and 85 ), and $F$. proliferatum (1 and 80 ) isolates; all but one $F$. commune isolate (FO21) were collected from koa. Of the 35 primer pairs, 7 (one designed to amplify the "core" chromosome 2 and 6 designed to amplify the LSX) did not amplify DNA from non-target species. The 6 primers designed to amplify the LSX did not result in amplification using DNA from Fo 170 or other characterized non-pathogenic $F$. oxysporum, $F$. commune, and F. proliferatum isolates. The primer developed on the "core" chromosome 2 (P4) resulted in amplification of DNA from two of the characterized non-pathogenic isolates (72 and 81). Of the primer pairs 
Table 2 Fusarium oxysporum f. sp. koae and F. oxyporum isolates that have been screened for pathogenicity through greenhouse virulence assays at the Hawai'i Agriculture Research Center

\begin{tabular}{llll}
\hline Isolate ID & Virulence & \% Mortality* & $\begin{array}{l}\text { Collection } \\
\text { Site (Island) }\end{array}$ \\
\hline 44 & High & 95 & Hawai'i \\
78 & High & 92 & Kauai \\
77 & High & 80 & Kauai \\
79 & High & 72 & Kauai \\
$0540 \mathrm{~K}$ & Moderate & 70 & Hawai'i \\
90 & Moderate & 68 & Oahu \\
20 & Moderate & 66 & Hawai'i \\
17 & Moderate & 62 & Hawai'i \\
166 & Moderate & 60 & Hawai'i \\
76 & Moderate & 60 & Kauai \\
8 & Moderate & 58 & Hawai'i \\
34 & Low & Hawai'i \\
72 & Nonpathogenic & 8 & Kauai \\
27 & Nonpathogenic & 8 & Maui \\
53 & Nonpathogenic & 4 & Maui \\
81 & Nonpathogenic & 4 & Kauai \\
170 & Nonpathogenic & 0 & Maui \\
\hline
\end{tabular}

*\% mortality of 24 inoculated seedlings per isolate displaying foliar wilt, chlorosis, and/or necrotic symptoms (Dudley et al. 2007; Dudley et al. 2017)

that did not amplify non-target Fusarium species, 2 of primer pairs P4 ("core") and P6 (LSX) were individually subjected to BLAST against the NCBI database to further test primers in silico for specificity (Additional File 5A). The "core" chromosome primer pair P4 had BLAST hits to other Fusarium spp. P4 forward and reverse primers had hits of 20 out 20 nucleotides to three genomes of F. xyrophilum, and 15 out of 20 nucleotides to F. fujikuroi and F. graminearum genomes, indicating this genomic region is likely found in other Fusarium spp. The LSX primer pair P6 also had partial BLAST hits to other Fusarium spp. in GenBank, including F. venenatum, F. fujikuroi, and F. graminearum, and the forward and reverse primers had 19 and 11 out of 20 nucleotides hits, respectively, to F. culmorum (Additional File 5B). Therefore, further testing of these primers, P4 and P6, on a broader suite of Fusarium spp. is warranted.

\section{Field isolate collection}

To test the specificity of primers P4 and P6 on a novel population of Fusarium isolates, root samples were collected from symptomatic koa trees. Root samples from 13 of the 14 sites surveyed in Hawai i yielded Fusarium isolates. A total of 359 Fusarium isolates, including $F$. oxysporum, F. solani, F. proliferatum, F. concolor, F. lateritium, F. commune, and F. fujikuroi (based on tef1 sequence data; GenBank Accession numbers and locations in Additional File 11), were collected from 100 symptomatic trees (70.4\% of surveyed symptomatic trees) across the three islands (Additional File 6). Most of the Fusarium isolates were obtained from Maunawili, Kalopa, Wood Valley, and Pa'auilo, respectively. The least represented sites were Kona, Wung Ranch, and Kaiwiki, respectively.

\section{Genetic characterization of field-collected isolates}

To genetically characterize field-collected isolates with known virulence isolates, the $r p b 2$ was sequenced for isolates from individual trees. Sequencing of $r p b 2$ was conducted on 100 isolates, including 16 characterized for pathogenicity ( 4 highly virulent, 6 moderately virulent, 1 low-virulence, and 5 non-pathogenic isolates) and 84 field-collected isolates (Additional File 7). Variation at the $r p b 2$ locus was used to construct a TCS haplotype network that resulted in 12 haplotypes (Fig. 3).

The haplotype network of the rpb2 revealed that the characterized highly virulent isolates $(\mathbf{4 4}, 77,78,79$, 90, and 166) belonged to the same haplotype, Hap_3 (Fig. 3). Moderately virulent isolates clustered within haplotypes Hap_1 and Hap_3, while the low-virulence isolate clustered in Hap_1. Non-pathogenic isolates clustered within four haplotypes, Hap_1, Hap_2, Hap_ 4, and Hap_6. The developed primer pair P4, developed to amplify DNA from "core" chromosome 2, amplified DNA from 3 of the 12 rpb2 haplotypes (Hap_1, Hap_3, and Hap_4), whereas the developed primer pair P6, developed to amplify LSX DNA, only amplified DNA from one haplotype (Hap_3) (Fig. 3). P4 produced amplification of DNA from highly virulent and moderately virulent isolates; however, P4 also amplified DNA from two non-pathogenic isolates (72 and 81) in Hap_4. DNA from uncharacterized isolates in Hap_1, Hap_3, and Hap_4 was amplified using the P4 primer pairs. The P6 primer pair did not produce amplification using DNA from non-pathogenic or lowly virulent isolates. The P6 primer pair amplified DNA from all but one uncharacterized isolate in Hap_3.

\section{Discussion}

Plant pathogenic fusaria have been assessed for interspecific genetic variation to identify genomic features important for plant host infection $[1,2]$. In addition, intraspecific genetic variation is a powerful tool to identify potential mechanisms for disease development by pathogenic fungi [31, 32]. This study presents a whole genome comparison between two $F$. oxysporum isolates collected from koa roots, one pathogenic (Fo koae 44) and one non-pathogenic (Fo 170) isolates. Through whole genome sequencing, genomic features were assessed bioinformatically for features that 


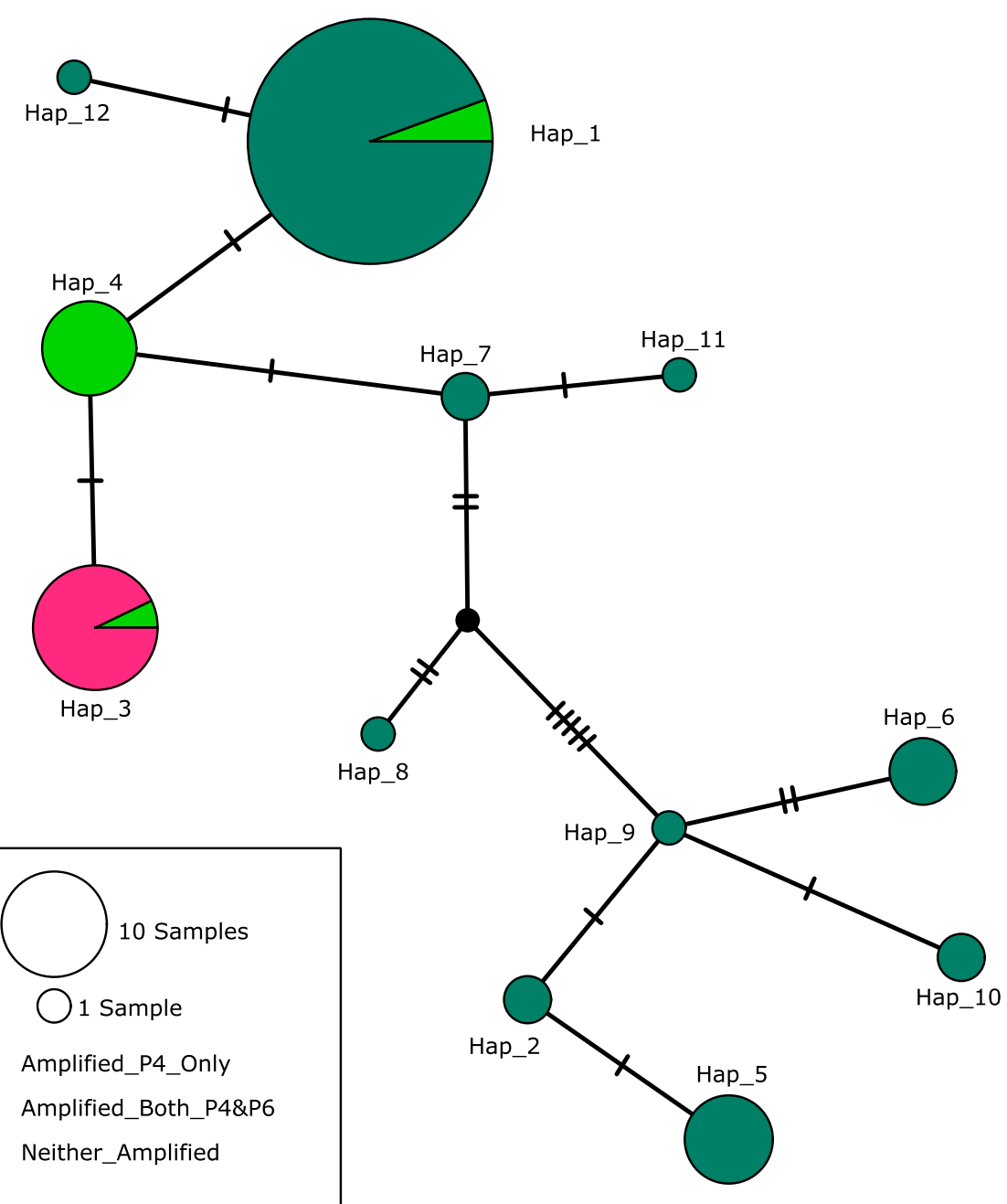

Fig. 3 RNA polymerase II second largest subunit (rpb2) haplotype network of 12 haplotypes identified from 100 Fusarium oxysporum and F. oxysporum f. sp. koae isolates including 84 untested, field-collected isolates and 16 characterized isolates of high, moderate, and low virulence and nonpathogenic. All highly virulent isolates clustered in the Hap_3 haplotype. Moderate and low virulence isolates clustered in the Hap_1 haplotype. The characterized non-pathogenic isolates clustered in the Hap_2, Hap_4, and Hap_6 haplotypes. The rpb2 haplotype network is overlaid with amplification from "core" chromosome primer pair P4 (designated by light green) and LSX primer pair P6 (designated in pink). Only the Hap_3 haplotype yielded amplification product with the LSX primer pair P6 from DNA of all highly virulent F. oxysporum f. sp. koae (Fo koae) and six uncharacterized isolates. Every isolate that amplified with the LSX primer pair also amplified with the "core" primer pair. "Core" chromosome primers (P4) produced amplification from three haplotypes including all highly virulent isolates in Hap_3 and two non-pathogenic isolates in Hap_4

distinguish the pathogen from the non-pathogen. Similar to other intraspecific comparison studies, the two genomes in this study were very similar [3]. They shared $96 \%$ average nucleotide identity (ANIm), indicating that they belong to the same species [33]. The constructed whole-genome phylogeny also confirmed that these isolates were among the F. oxysporum species complex (Additional File 1). Synteny analysis identified that the putative chromosomes in both isolates were syntenic amongst the 11 shared chromosomes of the well-characterized $F$. oxysporum f. sp. lycopersici isolate [18]. Analysis of the syntenic chromosomes coincided with a recent study that observed higher recombination at the telomeres and amongst smaller chromosomes, while larger chromosomes were more conserved [28]. A non-syntenic "chromosome" was identified in both genomes, which is likely where most of the genes necessary to differentiate the koa pathogen are localized (Fig. 1b). Genome size has been shown to be a putative indicator of pathogenicity in filamentous fungi. Compared to their non-pathogenic counterparts, pathogens generally utilize larger genomes, which is associated with the presence of conditionally dispensable, lineage-specific accessory chromosomes [19]. These accessory chromosomes are known to be ca. $2 \mathrm{Mb}$, and they frequently house effectors necessary for disease development or evasion of host detection [4]. Despite these reports, this study found that the 
non-pathogen (Fo 170) had a slightly larger genome compared to the pathogen (Fo koae 44 ) at 50 and $48 \mathrm{Mb}$, respectively. Though Fo 170 had a larger genome, this study identified unique genes and DNA sequences, most notably the well-characterized secreted in xylem effectors (SIX genes), that were exclusive to Fo koae 44. Most of these unique genomic features of Fo koae 44 were identified amongst the LSX.

As $F$. oxysporum does not have an observed teleomorphic life stage, it relies on asexual means of recombination. As such, conditionally dispensable, accessory chromosomes, and horizontal gene transfer have been described as being responsible for the host-specificity of the various formae speciales (ff. spp.) [19, 34, 35]. The predominant variation between $F$. oxysporum $\mathrm{ff}$. spp. has been found in effector profiles on these conditionally dispensable, accessory chromosomes [16]. Previous studies have suggested that repeats and transposons on the accessory chromosomes increase the occurrence of point mutations, which expands diversity in virulence genes through higher mutation and duplication rates via chromosomal rearrangements and altered gene expression through chromatin restructuring $[19,35]$. The identified LSX of Fo koae 44 in this study was transposonrich and contained important wilt-inducing effector genes, SIX1 and SIX6, providing evidence of one or more pathogen-specific, accessory chromosome(s). Interestingly, the identified LSX of Fo 170 was also transposon-rich, but it contained genes associated with root disease including the PEP2 gene. The LSX identified here likely represent a combination of multiple lineage-specific chromosomes, but due to the methodologies used in this study, the LSX likely also contains assembly contigs that did not map to the reference, but could still belong on core chromosomes. However, a portion of DNA found within the LSX likely represents one or more lineage-specific chromosome(s) for both Fo koae 44 and Fo 170. Future karyotyping studies could determine presence and quantity of accessory chromosomes. Virulence-associated genes within the LSX are likely the determining factors that distinguishes pathogenicity of Fo koae 44 on koa.

Even though 1353 and 2369 predicted proteins were identified on the LSX of Fo koae 44 and Fo 170, respectively, the function of 58 and $50 \%$ of genes for $F o$ koae 44 and Fo 170, respectively, could not be determined from the available databases used for this study (Additional File 8). Perhaps these genes are highly specific to Fo koae 44 and Fo 170 and are possibly important for pathogenicity but have yet to be described. Since we did not conduct transcriptomic analyses in this study, we could not validate expression of these genes. Amongst the identified genes, most virulence-associated genes, secondary metabolites, and carbohydrate active enzymes were found to be similar for Fo koae 44 and Fo 170. Several well-characterized, virulence-associated genes (e.g., Gpabc1, GzmetE, Tom1, Ace1, Mocdip1, Ftf2, and SGE1) were identified in both Fo koae 44 and Fo 170. Interestingly, these genes suggest that Fo koae 44 and Fo 170 both have the capacity for host recognition and disease development, even though Fo 170 does not cause wilt disease on koa [36].

Of the 57 and 59 unique predicted genes from the LSX of Fo koae 44 and Fo 170, respectively, the major distinctions found in Fo koae 44 were a mitogen-activated protein kinase pathway (associated with genes Fmk1, Ste11, and Ste7), which were previously identified as important for host penetration and pathogenicity, and the SIX1 and SIX6 [37]. SIX genes have been well-characterized as important host-specific pathogenicity factors in various $F$. oxysporum formae speciales $[15,18]$. SIX1 and SIX6 genes together have been reported in F. oxysporum f. sp. lycopersici, $F$. oxysporum f. sp. melonis, $F$. oxysporum f. sp. niveum, $F$. oxysporum f. sp. canariensis, $F$. oxysporum f. sp. phaseoli and $F$. oxysporum $\mathrm{f}$. sp. cubense [3, 16, 20,38-40]. With the banana pathogen, $F$. oxysporum f. sp. cubense (Fo cubense), tropical race 1 and tropical race 4 can be distinguished by SIX genes [41, 42]. The same SIX1 and SIX6 genes reported here in Fo koae 44 have been previously reported in Fo cubense race 1 [5]. SIX genes are surrounded by repeatand transposon-rich regions that increase the chances of mutation and duplication of these important effectors [19]. Our results concur with these previous observations because we observed the localization of the two SIX genes amongst the transposon-rich LSX of Fo koae 44 [29]. These $S I X$ genes, in conjunction with their associated transcription factor (SGE1) and the mitogen-activated protein kinase pathway, may be key characteristics that contribute to pathogenicity on koa.

Although Fo 170 lacked SIX genes, a stronger putative association was observed for secondary metabolite production and transport. The identification of the trehalose, putrescine, cyclodipeptide, and monooxygenase genes in Fo 170 signified that toxin production may be more important for disease development on a potential non-koa host of Fo 170. Interestingly, another secreted peptide, PEP2 (PHI:224), was identified as exclusive to $F o$ 170, and it has been found to be important for development of root rot on pea. These results also suggest that while Fo 170 does not cause koa wilt disease, it may be a pathogen on another host. To differentiate and monitor the koa wilt pathogen from its nonpathogenic counterparts, pathogen-specific primers were developed.

Pathogen-specific primers have previously been shown to be effective at detecting and monitoring pathogenic strains of fungi [43-47], and they are powerful tools in disease management, including disease resistance-breeding programs. Similar to recent studies, developed primers were based on unique non-coding sequences and exclusive 
predicted genes of Fo koae 44 [43-45]. To reduce the risk of false positive amplification of other $F$. oxysporum formae speciales isolated from koa, we chose to develop primers that would amplify genes unique to Fo koae 44 that did not have identified gene ontology terms.

Due to the importance of lineage-specific DNA and the virulence-associated genes found within, the LSX was targeted for primer development to detect the presence of the lineage-specific DNA that contains putative genes necessary for development of koa wilt disease $[3,16]$. We observed that primer pair P6 developed for the LSX was more reliable to distinguish pathogenic isolates than unique genes identified on the "core" chromosomes, because no non-target amplification of DNA from characterized non-pathogenic isolates was observed with the LSX primer pair (P6). Of the 12 identified $r p b 2$ haplotypes, primer pair $\mathrm{P} 4$ resulted in target amplification of three haplotypes (Hap_1, Hap_3, and Hap_4), but primer pair $\mathrm{P} 6$ produced target amplification of only one haplotype (Hap_3). These results indicate that isolates in haplotype Hap_3 may possess some putative lineage-specific DNA necessary for development of koa wilt disease. DNA of haplotypes that only amplified with primer pairs $\mathrm{P} 4$, may contain a homologous gene in their "core" chromosomes that may not be required for virulence that is also shared with other Fusarium spp.

The LSX primer pair (P6) resulted in amplification of DNA from only one $r p b 2$ haplotype which suggests that it may be too specific to amplify all highly virulent isolates within the Fo koae population; however, primer pair P6 produced amplified product for all pathogenic Fo koae isolates used in HARC's disease resistance breeding program. The seven Fo koae isolates used in HARC's disease resistance breeding program were collected on Hawai'i (44 and 166), Kauai (76, 77, 78, and 79), and Oahu (90); DNA from all of these isolates was amplified with both developed primer pairs [23, 48]. For the ongoing greenhouse pathogenicity trials, these highly virulent isolates (44, 77, 78, and 79) and three moderately virulent isolates $(76,90$, and 166) are combined evenly by weight and used in combination as a soil inoculum [23]. This methodology (mixing of inoculum from multiple isolates), may allow anastamoses and/or asexual genetic recombination to occur between isolates. Hypothetically, the putative lineage-specific DNA used to develop our primers could have been transferred horizontally among isolates during the inoculation trials conducted by HARC [7], which could have contributed to the observed amplification of a single haplotype with the developed P6 primer pair. Targeted studies of the Fo koae population are needed to better understand the role of horizontal gene transfer in pathogenicity.

Future studies should include greenhouse virulence assays to characterize field-collected isolates that amplified with both the core primer pair (P4) and the LSX primer pair (P6). Population genomic analyses are needed to determine genetic relationships among pathogenic Fo koae and non-pathogenic F. oxysporum isolates across the Hawaiian archipelago. Such studies can determine if a direct comparison of one pathogen and one nonpathogen is sufficient for developing a primer to detect pathogenic Fo koae, or if whole genome sequences of multiple haplotypes are needed to develop more robust, pathogen-specific primers. In addition, karyotyping could validate the presence and quantity of the putative lineage-specific chromosome(s) of Fo koae 44.

\section{Conclusion}

This study used whole genome analyses to predict virulence-associated genes that may be necessary for the development of koa wilt disease by Fo koae. This information was used to develop PCR primers for distinguishing highly virulent Fo koae isolates from non-pathogenic F. oxysporum isolates. Previously, the SIX1 and SIX6 genes have been characterized in other pathogens for their role in causing wilt diseases in other hosts, and it appears that these genes are also necessary for Fo koae to cause koa wilt disease. Genomic comparisons between Fo koae 44 and Fo 170 identified Fo 170exclusive genes, including pathogenicity-related genes, which suggests that Fo 170 may be pathogenic to a different host without necessarily causing a wilt disease. Putative lineage-specific chromosomes were identified, but further research is needed to characterize and quantify these chromosomes. Pathogen-specific primers were developed that only amplified DNA of characterized, pathogenic isolates of Fo koae.

Because virulence assays have not yet been conducted on Fo koae haplotype isolates from the field collection, further research is needed to assess the robustness of the developed primers and determine if the predicted virulence-associated genes are required for pathogenicity. These results provide the framework for understanding the pathogen genes necessary for development of koa wilt disease and determining genetic variation of Fo koae populations across the Hawaiian Islands.

\section{Methods}

Greenhouse-characterized pathogenic and nonpathogenic isolates of Fusarium oxysporum

For this study, Fusarium oxysporum isolates that were previously screened for pathogenicity through greenhouse trials were provided by the Hawai' $\mathrm{i}$ Agriculture Research Center (HARC) [48] (Table 2). These isolates were screened at HARC using methods described in Dudley et al. [48]. At 90 days post-inoculation of koa seedlings under greenhouse conditions, isolates were classified 
as non-pathogenic $(<10 \%$ mortality), low virulence $(10-$ $30 \%$ mortality), moderate virulence (30-70\% mortality), or high virulence (70-100\% mortality) (Table 2 ).

Twelve characterized pathogenic $F$. oxysporum isolates of high $(44,77,78$, and 79), moderate $(8,17,20,76,90$, 166 , and $0540 \mathrm{~K})$, and low (34) virulence, and five nonpathogenic $(27,53,72,81$, and 170) F. oxysporum isolates were used for reference in later analyses. Isolates $44,76,77,78,79,90$, and 166 are currently used in HARC's disease resistance screening trials. Pathogenic isolate 44 and non-pathogenic isolate 170 were selected for whole genome sequencing.

\section{Whole genome sequencing and assembly}

In preparation for DNA extraction, one isolate pathogenic to koa ( $F o$ koae 44) and one non-pathogenic isolate (Fo 170) were first grown on $1 / 4$-strength PDA at $25^{\circ} \mathrm{C}$ for 3 days. Hyphal tips were transferred to $100 \mathrm{ml}$ of potato dextrose broth and shaken at $70 \mathrm{rpm}$ for 7 days at room temperature. Mycelium was collected using a Buchner funnel and filtered through a Whatman ${ }^{\circ}$ No. 1 filter paper under vacuum. Mycelium was placed in 2-ml tubes and frozen at $75^{\circ} \mathrm{C}$ for $24 \mathrm{~h}$ prior to extraction. DNA was extracted using a cetyl trimethyl ammonium bromide (CTAB) extraction protocol adapted from Cubero et al. [49]. Tissue preparation was modified from the original protocol in that $0.1 \mathrm{~g}$ of frozen tissue was pulverized using a FastPrep-24 ${ }^{\mathrm{Tm}}$ (M.P. Biomedicals LLC, Santa Ana, CA, USA) at 5x speed for three 20-s runs. Between runs, samples were kept frozen using liquid nitrogen. On the third run, $750 \mu$ of CTAB extraction buffer (1\% w/v CTAB; $1 \mathrm{M} \mathrm{NaC1;} 100 \mathrm{mM}$ Tris; 20 mM EDTA; $1 \% \mathrm{w} / \mathrm{v}$ polyvinyl polypyrolidone) was added to each sample. Samples were incubated for $30 \mathrm{~min}$ at $70{ }^{\circ} \mathrm{C}$ in a heat block. One volume of chloroform:isoamyl alcohol (24:1) was added to each sample and mixed on a shaker for $20 \mathrm{~min}$ then centrifuged at $10,000 \mathrm{x}$ g for 5 min. Upper aqueous phase $(600 \mu \mathrm{l})$ was transferred to a new 2-ml tube. Two volumes of Precipitation buffer (two volumes; $1200 \mu \mathrm{l}$ ) was added to sample, which was mixed in a shaker for $5 \mathrm{~min}$, then centrifuged at 13,000 $\mathrm{x}$ $\mathrm{g}$ for $15 \mathrm{~min}$. Supernatant was removed and re-suspended in $350 \mu \mathrm{l} 1.5 \mathrm{M} \mathrm{NaCl}$. To each sample, $2 \mu \mathrm{l}$ of $10 \mathrm{mg} / \mathrm{ml}$ RNase was added, followed by incubation at $37^{\circ} \mathrm{C}$ for 30 min. One volume of chloroform:isoamyl was added to each sample and mixed on a shaker for $20 \mathrm{~min}$, then centrifuged at $10,000 \mathrm{x}$ g for $5 \mathrm{~min}$. Upper phase was transferred to a new $1.5-\mathrm{ml}$ tube and 0.6 volume of icecold isopropanol was added to each sample. Samples were mixed by inversion and incubated at $-20^{\circ} \mathrm{C}$ for $1 \mathrm{~h}$. After incubation, samples were centrifuged at $14,000 \mathrm{x}$ g for 5 min at room temperature. Supernatant was removed and $1 \mathrm{ml} 70 \%$ ethanol was added to each sample. After 1-min incubation at room temperature, samples were centrifuged at $14,000 \mathrm{x} \mathrm{g}$ for $3 \mathrm{~min}$ at room temperature. Pellet was dried and resuspended in $50 \mu \mathrm{l}$ TE buffer $(10 \mathrm{mM}$ Tris$\mathrm{HCl}, 1 \mathrm{mM}$ EDTA). Extracted DNA was gel electrophoresed in a $2 \%$ agarose gel and quantified using a Qubit ${ }^{\mathrm{ma}}$ fluorometer (Invitrogen, Carlsbad, CA, USA). A Zymoclean $^{\text {tw }}$ Gel DNA Recovery Kit (Zymo Research, Irvine CA, USA) and a Zymo clean and concentrate column were used to recover and purify the DNA. Extracted DNA was sent to Macrogen (Seoul, South Korea) for TruSeq Illumina shotgun sequencing with reads of 2x151bp.

De novo genome assemblies of both Fo koae 44 and Fo 170 were constructed using SPAdes 3.11.1 [50] using default parameters. The SPAdes genome assembly was assessed for quality using QUAST [51]. Contigs with than 100x coverage were removed, and the remaining contigs were checked for similarity with Fusarium spp. sequences using the National Center for Biotechnology Information (NCBI) BLAST to screen for presence of bacterial DNA in samples.

\section{Phylogenetic analysis}

A whole-genome, maximum likelihood phylogeny was constructed to elucidate evolutionary relationships among Fo koae 44, Fo 170, other Fusarium spp., and other F. oxysporum formae speciales. REALPHY 112 [52] was used to generate whole genome alignments including the $F$. oxysporum f. sp. lycopersici reference genome and Magnaporthe oryzae (Both obtained from GenBank; Additional File 9). PhyML 3.1 [53] using bowtie2 2.3.4.2 [54] and the general time reversal (GTR) substitution model [55], was used to construct the whole genome phylogeny with bootstrap support (pseudoreplicates $=200$ ) and $M$. oryzae as the outgroup. Whole genomes of Fusarium spp. and $F$. oxysporum formae speciales were obtained from the NCBI GenBank database (Additional File 9).

\section{Genome annotation and analysis}

To determine overall sequence similarity of Fo koae 44 and Fo 170 isolates, average nucleotide identity was calculated using Pyani [56]. R package 'coRdon' was used to determine codon usage bias $[57,58]$. TransposableELMT, a wrapper script for transposable element identification, and creation of a comprehensive repeat library using RepeatModeler, RepeatClassifier, LTR_finder, ltr harvest, and TransposonPSI (http://transposonpsi.sour ceforge.net) and subsequently RepeatMasker with this library were used to identify transposable elements and repeat-rich regions for both Fo koae 44 and Fo 170 [59-61].

To identify unique sequences of Fo koae 44 and Fo 170, putative chromosomes were constructed using a closely related reference genome, $F$. oxysporum f. sp. lycopersici. Paired reads of the genomes of Fo koae 44 and Fo 170 were trimmed using BBDuk (decontamination using kmers; part of BBTools package) [62]. The trimmed reads 
were mapped to the reference genome using Geneious (Geneious Prime 2019.2, http://www.geneious.com/) progressiveMauve genome mapper software at medium-low sensitivity [63, 64]. Low and high coverage sites were removed using Geneious' built-in program. Variants and SNPs were identified using FreeBayes [65] within Geneious. Variant calling format (VCF) was exported for use in comparison of SNPs and indels between Fo koae 44 and Fo 170. Synteny maps and MUMmer alignments were made using the synteny mapping and analysis program (SyMAP) [66] to create putative chromosome contigs based on the reference genome.

The de novo assembled genomes were annotated for both Fo koae 44 and Fo 170 using the MAKER 2.31.8 annotation pipeline [67] with RepeatMasker 4.0.8 [60]. A F. oxysporum-specific repeat library was constructed using RepeatModeler 1.0.11 [68] to mask interspersed repeats and low complexity DNA sequences. Three gene predictors were used in the pipeline: GeneMark-ES [69], SNAP [70], and AUGUSTUS [71]. Fusarium graminearum was used as a species model for AUGUSTUS. To identify tRNA genes, tRNAscan-SE 1.3.1 was used with default settings.

Predicted transcripts $(\geq 150 \mathrm{bp})$ and proteins ( $\geq 50$ amino acids) were analyzed using five databases for analysis of putative genes: OrthoVenn2 for putative non-orthologous proteins [72], InterProScan for protein family domains [36], antiSMASH for putative secondary metabolites [73], dbCAN2 for putative carbohydrate-active enzymes [30], and PHI-base for putative virulence-associated proteins [74]. OrthoVenn2, antiSMASH, and dbCAN2 databases' online servers were used to analyze the predicted genes at default settings. A local BLAST was used for InterProScan and the PHI-base database. Selection of putative proteins from PHI-base was based on $a \geq 85 \%$ grade (metric of combining the query coverage, e-value, and identity values for each hit with weights of $0.5,0.25$ and 0.25 , respectively). Putative virulence-associated proteins were tested for exclusivity to Fo koae 44 by aligning these sequences to sequences obtained from the NCBI database using MUSCLE in Geneious [75] (Additional File 10).

\section{Primer development}

Putative chromosomes from SyMAP were aligned using progressiveMauve [63] in Geneious. Using these alignments, unique sequences of Fo koae 44 were identified and selected. Also, predicted transcripts specific to Fo koae 44 were identified by comparing the predicted transcriptomes of Fo koae 44 and Fo 170 from the Maker annotation identified from Orthovenn2. Fo koae 44 predicted transcripts were further identified as unique by using a local BLAST against Fo 170 and the NCBI database. Sequences with no sequence similarity to sequences from Fo 170, other Fusarium spp., and $F$. oxysporum formae speciales were used to develop primer pairs. Primer3 [76] was used to develop PCR primers. Fo koae 44 unique sequences and predicted transcripts were used to generate ca. ten primer sets (forward and reverse primers) for each sequence and transcript.

Primers were tested for specificity using template DNA from four characterized highly virulent Fo koae isolates (isolates used in HARC greenhouse screening trials: 44, 77, 78, and 79), seven characterized moderately virulent Fo koae isolates (HARC isolates 8, 17, 20, 76, 90, 166, and $0540 \mathrm{~K})$, two characterized non-pathogenic Fo isolates (HARC isolates 27 and 170), two F. commune isolates (HARC isolate 85 and Stewart collection FO21), and one $F$. proliferatum isolate (HARC isolate 1 ). Each 25 -ul reaction contained $10 \mathrm{ng}$ template DNA or sterile, molecular grade water for the negative control. Primers were tested using a Mastercycler ProS thermocycler (Eppendorf, Hamburg, Germany) at a program of $94^{\circ} \mathrm{C}$ for $2 \mathrm{~min}$, 30 cycles of $94{ }^{\circ} \mathrm{C}$ for $40 \mathrm{~s}, 59^{\circ} \mathrm{C}$ for $40 \mathrm{~s}$, and $72^{\circ} \mathrm{C}$ for 30 $\mathrm{s}$, and $72^{\circ} \mathrm{C}$ for $5 \mathrm{~min}$. PCR products for each primer set and template DNA were electrophoresed using a standard $1.5 \%$ agarose gel at $60 \mathrm{~V}$ for $60 \mathrm{~min}$, and visualized using GelRed $^{\circ}$ (Biotium, Freemont, CA, USA).

\section{Field collection of Fusarium spp.}

To assemble an expanded population of $F$. oxysporum isolates for Fo koae specific-primer tests, 14 collection sites were selected based on a previous survey conducted by HARC from 2004 to 2007 across four of the main Hawaiian Islands, including Kauai, Oahu, Maui, and Hawai'i [77]. Sites for new isolate collections were selected based sites on where previously characterized pathogen isolates of moderate to high virulence were collected. In addition, selected collection sites were geographically distant from each other to increase the likelihood of collecting a more genetically diverse pathogen population. On Kauai, the three collection sites included Kokee, Kapa'a, and Hanalei (Princeville). On Oahu, three collection sites included Maunawili, Poamoho, and Kahana. On Hawai i, eight collection sites included Wood Valley, Pu'u wa'a wa'a, Kona, Wung Ranch, Kaiwiki, Kalopa, Paauilo, and Volcano National Park. Root samples were collected from symptomatic trees at each site. Symptomatic segments of 4- to 5-mm thick roots exhibiting discoloration and black streaking, were targeted for isolation of Fusarium spp. Five fine roots and/or pencil-thick roots were plated on selective Komada media [78] for isolation of Fusarium spp. Plates were incubated at $25^{\circ} \mathrm{C}$ for 3 days then checked for mycelial growth emanating from the root samples. Hyphal tips were taken from the radiating mycelium and transferred to $1 / 4$-strength PDA and incubated at $25^{\circ} \mathrm{C}$ for another 3 days. Colony morphology was used to determine if the isolate was Fusarium. To further characterize these isolates to species, isolates were sequenced at the translation elongation factor 1 alpha (tef1) region using a Mastercycler ProS thermocycler and a PCR 
cycle program of $94{ }^{\circ} \mathrm{C}$ for $2 \mathrm{~min}, 40$ cycles of $94{ }^{\circ} \mathrm{C}$ for $40 \mathrm{~s}$, $58^{\circ} \mathrm{C}$ for $40 \mathrm{~s}$, and $72{ }^{\circ} \mathrm{C}$ for $30 \mathrm{~s}$, and $72{ }^{\circ} \mathrm{C}$ for $5 \mathrm{~min}$ [79]. Products were run on a $1.5 \%$ agarose gel to visualize amplified PCR product using GelRed ${ }^{\circ}$.

\section{Genetic characterization of field-collected isolates}

To determine the genetic relationships among the fieldcollected isolates and the previously characterized pathogenic and non-pathogenic isolates, F. oxysporum isolates, based of tef1 data. Isolates were selected from separate, individual trees. The selected isolates were then sequenced at the RNA polymerase II second largest subunit ( $r p b 2)$ [80] using previous methods above for tef1. $R p b 2$ sequences of both characterized and field-collected isolates were aligned using MUSCLE alignment in Geneious [75]. A statistical parsimony (TCS) haplotype network was constructed based on this $r p b 2$ sequence data using PopART with a 95\% genetic cut-off [81]. These isolates were tested with the developed Fo koae-specific primers to identify haplotypes that may contain the putative lineagespecific DNA identified from Fo koae 44.

\section{Supplementary information}

Supplementary information accompanies this paper at https://doi.org/10. 1186/s12864-020-07156-y.

Additional file 1. Whole genome maximum likelihood phylogeny based on Fusarium spp. and F. oxysporum (Fo) formae speciales. Pathogenic isolate F. oxysporum f. sp. koae (Fo koae 44) indicated in red and nonpathogenic isolate F. oxysporum (Fo 170) indicated in blue. Bootstrap $=$ 100.

Additional file 2. Putative biological, molecular, and cellular function of the predicted non-orthologous proteins identified as unique to the pathogenic isolate of Fusarium oxysporum f. sp. koae (Fo koae 44) when compared to non-pathogenic isolate of F. oxysporum (Fo 170). Identified function is based on gene ontology (GO) terms.

Additional file 3. Putative biological process and molecular function of the predicted non-orthologous proteins identified as unique to the nonpathogenic Fusarium oxysporum isolate (Fo 170) when compared to the pathogenic isolate of F. oxysporum f. sp. koae (Fo koae 44). Function is based on gene ontology (GO) terms.

Additional file 4. Copy number of secondary metabolite genes including nonribosomal peptide synthetases (NRPS), type 1 and type 3 polyketide synthases (T1PKS and T3PKS), terpenes, and indoles for the pathogenic Fusarium oxysporum f. sp. koae isolate (Fo koae 44, red bars) and non-pathogenic F. oxysporum isolate (Fo 170, blue bars).

Additional file 5. A) Pathogen-specific PCR primers designed from unique genes and sequences in genome of Fusarium oxysporum f. sp. koae 44. Isolates were confirmed for pathogen specificity through PCR testing on greenhouse-characterized pathogenic and non-pathogenic isolates provided by the Hawai'i Agriculture Research Center. B) NCBI BLAST results of primer pairs P4 (designed to amplify "core" chromosome 2) and P6 (designed to amplify the putative lineage-specific DNA, LSX, of Fo koae 44).

Additional file $\mathbf{6}$. Results of 2018 field collection showing number of Fusarium isolates collected from symptomatic Acacia koa.

Additional file 7. Distribution and virulence ratings for 15 characterized and 85 uncharacterized Fusarium oxysporum isolates collected from Acacia koa roots used for haplotype and primer amplification analysis.
Additional file 8. Proportion of predicted genes with putative function of the lineage specific DNA (LSX) of the Acacia koa wilt pathogen Fusarium oxysporum f. sp. koae (Fo koae 44) and the F. oxysporum (Fo 170) isolate characterized as non-pathogenic to $A$. koa. Both isolates had similar proportions of transposons, repeats, carbohydrate active enzymes (CAZymes), and genes identitifed through gene ontology terms and protein family as having a biological, molecular, or cellular function. Fo koae 44 had a higher proportion of virulence associated genes and Fo 170 had a higher proportion of secondary metabolite genes on the LSX.

Additional file 9. Whole genome sequences of Fusarium spp. and formae speciales of $F$. oxysporum retrieved from NCBI with GenBank or RefSeq accession numbers. These genomes were used to make the whole genome phylogeny.

Additional file 10. Secreted in xylem $(S I X)$ gene sequences of formae speciales of Fusarium oxysporum (Fo) retrieved from NCBI with GenBank accession numbers. Sequences used to compare identified SIX genes in pathogenic isolate F. oxysporum f. sp. koae 44.

Additional file 11. GenBank accession numbers and collection locations for all isolates used in this study.

\section{Abbreviations}

Fo koae: Fusarium oxysporum f. sp. koae; Fo: Fusarium oxysporum; koa: Acacia koa; rpb2: RNA polymerase II second largest subunit; tef1: Translation elongation factor 1 alpha; HARC: Hawai'i Agriculture Research Center; LSX: Putative lineage-specific DNA; DNA: Deoxyribonucleic acid; Hap: Haplotype; SIX: Secreted in xylem; ANIm: Average nucleotide identity; GO: Gene ontology; NRPS: Non-ribosomal peptide synthetases; ABC: ATPbinding cassette; PCR: Polymerase chain reaction; CTAB: Cetyl trimethyl ammonium bromide; GTR: General time reversal; NCBI: National Center for Biotechnology Information; SNP: Single nucleotide polymorphism; VCF: Variant calling format; SyMAP: Synteny mapping and analysis program

\section{Acknowledgements}

We acknowledge Kristen Otto for her technical assistance, Jorge IbarraCaballero for help in DNA extractions and bioinformatics analysis, and Stephen Wyka for assistance in identifying transposable elements.

\section{Authors' contributions}

JTD participated in the conception and design of the study, performed/ assisted in field isolate collections, performed statistical and genomic analyses, and drafted manuscript. JES participated in securing funding, in the conception and design of the study, performed/ assisted in field isolate collections, performed statistical and genomic analyses, and drafted manuscript. MSK and NBK participated in securing funding, in the conception and design of the study, performed/ assisted in field isolate collections, and drafted manuscript. NSD for acquiring HARC isolates and assisting in design of field isolate collections. NSD, RKD and PGC assisted with critical evaluation of the manuscript. RDH, AY, and TCJ assisted/ participated in field isolate collection, obtaining site access, and assisted in design of field isolate collections. All authors have read and approved the final version of the manuscript.

\section{Funding}

This work was funded by a grant from the USDA Forest Service, Forest Health Protection, Special Technology Development Program (R5-FY2017-3). The funder had no role in the study.

\section{Availability of data and materials}

Cultures used in this study are stored at Colorado State University Stewart laboratory culture collection and are available upon request. All sequences have been deposited into National Center for Biotechnology Information (NCBI) BioPoject, BioSample, Nucleotide and GenBank and accession numbers are listed in Additional File 5B and Additional File 11. Site information including GPS locations, where available, are listed in Additional File 7 and Additional File 11 for each isolate. GenBank accession numbers of isolates used for comparison of secreted in xylem genes are listed in Additional File 10. GenBank accession numbers for reference genomes and genomes used for whole genome comparisons are listed in Additional File 9. 


\section{Ethics approval and consent to participate}

Site access permissions as well as state and federal collection and shipping permits were obtained prior and issued by the US Dept of Interior National Park Service and the Department of Land and Natural Resources Division of Forestry and Wildlife to sample collections and USDA APHIS to ship samples from Hawaii to Colorado, USA.

\section{Consent for publication}

Not applicable.

\section{Competing interests}

The authors declare that they have no completing interests.

\section{Author details}

${ }^{1}$ Colorado State University, Department of Agricultural Biology, 1177 Campus Delivery, Fort Collins, CO 80523, USA. ²USDA Forest Service, Pacific Northwest Research Station, 3200 SW Jefferson Way, Corvallis, OR 97331, USA. 'Hawai'i Agriculture Research Center, Maunawili Research Station, Oahu, HI, USA. ${ }^{4}$ USDA Forest Service, Rocky Mountain Research Station, 1221 South Main Street, Moscow, ID 83843, USA. ${ }^{5}$ Division of Forestry and Wildlife, Department of Land and Natural Resources, 1151 Punchbowl Street, Room 325, Honolulu, HI 96813, USA. ${ }^{6}$ USDA Forest Service, Forest Health Protection, 1323 Club Drive, Vallejo, CA 94592, USA.

Received: 19 May 2020 Accepted: 15 October 2020 Published online: 04 November 2020

\section{References}

1. Sperschneider J, Gardiner DM, Thatcher LF, Lyons R, Singh KB, Manners JM, Taylor JM. Genome-wide analysis in three Fusarium pathogens identifies rapidly evolving chromosomes and genes associated with pathogenicity. Genome Biol Evol. 2015;7(6):1613-27. https://doi.org/10.1093/gbe/evv092.

2. Walkowiak S, Rowland O, Rodrigue N, Subramaniam R. Whole genome sequencing and comparative genomics of closely related Fusarium head blight fungi: Fusarium graminearum, F. meridionale and F. asiaticum. BMC Genomics. 2016;17(1):1014. https://doi.org/10.1186/s12864-016-3371-1.

3. Armitage AD, Taylor A, Sobczyk MK, Baxter L, Greenfield BPJ, Bates HJ, Wilson F, Jackson AC, Ott S, Harrison RJ, Clarkson JP. Characterization of pathogen-specific regions and novel effector candidates in Fusarium oxysporum f. sp. cepae. Scientific reports. 2018;8(1):13530. https://doi.org/10. 1038/s41598-018-30335-7.

4. Bertazzoni S, Williams AH, Jones DA, Syme RA, Tan K-C, Hane JK. Accessories make the outfit: accessory chromosomes and other dispensable DNA regions in plant-pathogenic fungi. Mol Plant-Microbe Interact. 2018;31(8): 779-88. https://doi.org/10.1094/MPMI-06-17-0135-Fl.

5. Deltour P, França SC, Heyman L, Pereira OL, Höfte M. Comparative analysis of pathogenic and nonpathogenic Fusarium oxysporum populations associated with banana on a farm in Minas Gerais, Brazil. Plant Pathol. 2018; 67(3):707-18. https://doi.org/10.1111/ppa.12757.

6. Liu X, Xing M, Kong C, Fang Z, Yang L, Zhang Y, Wang Y, Ling J, Yang Y, LV $\mathrm{H}$. Genetic diversity, virulence, race profiling, and comparative genomic analysis of the Fusarium oxysporum f. sp. conglutinans strains infecting cabbages in China. Frontiers in. Microbiology. 2019;10:1373. https://doi.org/ 10.3389/fmicb.2019.01373.

7. Li J, Fokkens L, Conneely $\sqcup$, Rep M. A partial pathogenicity chromosome in Fusarium oxysporum is sufficient to cause disease and can be horizontally transferred [preprint]. Microbiology. 2020. https://doi.org/10.1101/2020.01.20. 912550.

8. Jiang C, Zhang X, Liu H, Xu J-R. Mitogen-activated protein kinase signaling in plant pathogenic fungi. PLoS Pathog. 2018;14(3):e1006875. https://doi. org/10.1371/journal.ppat.1006875.

9. Ponukumati SV, Elliott ML, Des Jardin EA. Comparison of secreted in xylem (SIX) genes in two Fusarium wilt pathogens of ornamental palms. Plant Pathol. 2019;68(9):1663-81. https://doi.org/10.1111/ppa.13090.

10. Taylor A, Vágány V, Jackson AC, Harrison RJ, Rainoni A, Clarkson JP. Identification of pathogenicity-related genes in Fusarium oxysporum f. sp. cepae: pathogenicity in Fusarium oxysporum f. sp. cepae. Mol Plant Pathol. 2016;17(7):1032-47. https://doi.org/10.1111/mpp.12346.

11. Thatcher LF, Gardiner DM, Kazan K, Manners JM. A highly conserved effector in Fusarium oxysporum is required for full virulence on Arabidopsis. Mol
Plant-Microbe Interact. 2012;25(2):180-90. https://doi.org/10.1094/MPMI-0811-0212.

12. Roy A, Jayaprakash A, Rajeswary TR, Annamalai A, Lakshmi P. Genome-wide annotation, comparison and functional genomics of carbohydrate-active enzymes in legumes infecting Fusarium oxysporum formae speciales. Mycology. 2020;11(1):56-70. https://doi.org/10.1080/21501203.2019.1706656.

13. Guo L, Han L, Yang L, Zeng H, Fan D, Zhu Y, Feng Y, Wang G, Peng C, Jiang X, Zhou D, Ni P, Liang C, Liu L, Wang J, Mao C, Fang X, Peng M, Huang J. Genome and transcriptome analysis of the fungal pathogen Fusarium oxysporum f. sp. cubense causing banana vascular wilt disease. PLoS ONE. 2014;9(4):e95543. https://doi.org/10.1371/journal.pone.0095543.

14. Chang W, Li H, Chen H, Qiao F, Zeng H. Identification of mimp-associated effector genes in Fusarium oxysporum f. sp. cubense race 1 and race 4 and virulence confirmation of a candidate effector gene. Microbiological Research. 2020;232:126375. https://doi.org/10.1016/j.micres.2019.126375.

15. Schmidt SM, Houterman PM, Schreiver I, Ma L, Amyotte S, Chellappan B, Boeren S, Takken FLW, Rep M. MITEs in the promoters of effector genes allow prediction of novel virulence genes in Fusarium oxysporum. BMC Genomics. 2013;14(1):119. https://doi.org/10.1186/1471-2164-14-119.

16. van Dam P, Fokkens L, Schmidt SM, Linmans JHJ, Kistler HC, Ma L-J, Rep M. Effector profiles distinguish formae speciales of Fusarium oxysporum: effector profiles distinguish formae speciales of Fo. Environ Microbiol. 2016; 18(11):4087-102. https://doi.org/10.1111/1462-2920.13445.

17. Gordon TR. Fusarium oxysporum and the Fusarium wilt syndrome. Annu Rev Phytopathol. 2017;55(1):23-39. https://doi.org/10.1146/annurev-phyto080615-095919.

18. Ma L-J, van der Does HC, Borkovich KA, Coleman JJ, Daboussi M-J, Di Pietro A, Dufresne M, Freitag M, Grabherr M, Henrissat B, Houterman PM, Kang S, Shim W-B, Woloshuk C, Xie X, Xu J-R, Antoniw J, Baker SE, Bluhm BH, Breakspear A, Brown DW, Butchko RAE, Chapman S, Coulson R, Coutinho PM, Danchin EGJ, Diener A, Gale LR, Gardiner DM, Goff S, Hammond-Kosack KE, Hilburn K, Hua-Van A, Jonkers W, Kazan K, Kodira CD, Koehrsen M, Kumar L, Lee Y-H, Li L, Manners J, Miranda-Saavedra D, Mukherjee M, Park G, Park J, Park S-Y, Proctor RH, Regev A, Ruiz-Roldan MC, Sain D, Sakthikumar S, Sykes S, Schwartz DC, Turgeon BG, Wapinski I, Yoder O, Young S, Zeng Q, Zhou S, Galagan J, Cuomo CA, Kistler HC, Rep M. Comparative genomics reveals mobile pathogenicity chromosomes in Fusarium. Nature. 2010;464(7287): 367-73. https://doi.org/10.1038/nature08850.

19. Raffaele S, Kamoun S. Genome evolution in filamentous plant pathogens: why bigger can be better. Nat Rev Microbiol. 2012;10(6):417-30. https://doi. org/10.1038/nrmicro2790.

20. van Dam P, Fokkens L, Ayukawa $Y$, van der Gragt M, ter Horst A, Brankovics B, Houterman PM, Arie T, Rep M. A mobile pathogenicity chromosome in Fusarium oxysporum for infection of multiple cucurbit species. Sci Rep. 2017;7(1):9042. https://doi.org/10.1038/s41598-017-07995-y.

21. Anderson, R. C., Gardner, D. E., Daehler, C. C., \& Meinzer, F. C. (2002). Dieback of Acacia koa in Hawaii: ecological and pathological characteristics of affected stands. For Ecol Manag, 162(2-3), 273-286. https://doi.org/10.1016/ S0378-1127(01)00522-9.

22. Gardner DE. Acacia koa seedling wilt caused by Fusarium oxysporum f. sp. koae, f. sp. nov. Phytopathology. 1980;70:594-7.

23. Dudley NS, Jones TC, James RL, Sniezko RA, Cannon P, Borthakur D. Applied disease screening and selection program for resistance to vascular wilt in Hawaiian Acacia koa. Southern Forests: A Journal of Forest Science. 2015; 77(1):65-73. https://doi.org/10.2989/20702620.2015.1007263.

24. Dudley, N., Jones, T., James, R., Sniezko, R., Wright, J., Liang, C., Gugger, P. F., \& Cannon, P. (2017). Applied genetic conservation of Hawaiian Acacia koa: An ecoregional approach. In: Sniezko, Richard A.; Man, Gary; Hipkins, Valerie; Woeste, Keith; Gwaze, David; Kliejunas, John T.; McTeague, Brianna A., tech. cords. 2017. Gene conservation of tree species_-banking on the future. Proceedings of a workshop. Gen. Tech. Rep. PNW-GTR-963. Portland, OR: US Department of Agriculture, Forest Service, Pacific Northwest Research Station, 963, 78-91.

25. Dudley, N., James, R., Sniezko, R., Cannon, P., Yeh, A., Jones, T., \& Kaufmann, M. (2012). Operational disease screening program for resistance to wilt in Acacia koa in Hawaii. In: Sniezko, Richard A.; Yanchuk, Alvin D.; Kliejunas, John T.; Palmieri, Katharine M.; Alexander, Janice M.; Frankel, Susan J., tech. coords. Proceedings of the fourth international workshop on the genetics of host-parasite interactions in forestry: Disease and insect resistance in forest trees. Gen. Tech. Rep. PSW-GTR-240. Albany, CA: Pacific Southwest Research Station, Forest Service, US Department of Agriculture, 240, 286-289. 
26. Ma L-J, Geiser DM, Proctor RH, Rooney AP, O'Donnell K, Trail F, Gardiner DM, Manners JM, Kazan K. Fusarium pathogenomics. Annu Rev Microbiol. 2013; 67(1):399-416. https://doi.org/10.1146/annurev-micro-092412-155650.

27. Takken F, Rep M. The arms race between tomato and Fusarium oxysporum. Mol Plant Pathol. 2010;11(2):309-14. https://doi.org/10.1111/j.1364-3703. 2009.00605.x.

28. Fokkens L, Shahi S, Connolly LR, Stam R, Schmidt SM, Smith KM, Freitag M, Rep $M$. The multi-speed genome of Fusarium oxysporum reveals association of histone modifications with sequence divergence and footprints of past horizontal chromosome transfer events [preprint]. Genomics. 2018. https:// doi.org/10.1101/465070.

29. Suga H, Hirayama Y, Morishima M, Suzuki T, Kageyama K, Hyakumachi M. Development of PCR primers to identify Fusarium oxysporum f. sp. fragariae. Plant Dis. 2013;97(5):619-25. https://doi.org/10.1094/PDIS-07-120663-RE.

30. Zhang $H$, Yohe $T$, Huang $L$, Entwistle $S$, Wu P, Yang Z, Busk PK, Xu Y, Yin Y. dbCAN2: A meta server for automated carbohydrate-active enzyme annotation. Nucleic Acids Res. 2018;46(1):95-101. https://doi.org/10.1093/ nar/gky418.

31. Carmona SL, Burbano-David D, Gómez MR, Lopez W, Ceballos N, CastañoZapata J, Simbaqueba J, Soto-Suárez M. Characterization of pathogenic and nonpathogenic Fusarium oxysporum isolates associated with commercial tomato crops in the Andean region of Colombia. Pathogens. 2020;9(1):70. https://doi.org/10.3390/pathogens9010070.

32. Seo S, Pokhrel A, Coleman JJ. The genome sequence of five genotypes of Fusarium oxysporum f. sp. vasinfectum: A resource for studies on Fusarium wilt of cotton. Mol Plant-Microbe Interact. 2020;33(2):138-40. https://doi.org/ 10.1094/MPMI-07-19-0197-A.

33. Figueras MJ, Beaz-Hidalgo R, Hossain MJ, Liles MR. Taxonomic affiliation of new genomes should be verified using average nucleotide identity and multilocus phylogenetic analysis. Genome Announcements. 2014;2(6): e00927-14, 2/6/e00927-14. https://doi.org/10.1128/genomeA.00927-14.

34. Mehrabi R, Mirzadi Gohari A, Kema GHJ. Karyotype variability in plantpathogenic fungi. Annu Rev Phytopathol. 2017;55(1):483-503. https://doi. org/10.1146/annurev-phyto-080615-095928.

35. Rep M, Van Der Does HC, Meijer M, Van Wijk R, Houterman PM, Dekker HL, De Koster CG, Cornelissen BJC. A small, cysteine-rich protein secreted by Fusarium oxysporum during colonization of xylem vessels is required for 1 3-mediated resistance in tomato: cysteine-rich protein required for $1-3-$ mediated resistance. Mol Microbiol. 2004;53(5):1373-83. https://doi.org/10. 1111/j.1365-2958.2004.04177.x.

36. Quevillon E, Silventoinen V, Pillai S, Harte N, Mulder N, Apweiler R, Lopez R. InterProScan: protein domains identifier. Nucleic Acids Res. 2005;33(web server):W116-20. https://doi.org/10.1093/nar/gki442.

37. Di Pietro A, Madrid MP, Caracuel Z, Delgado-Jarana J, Roncero MIG. Fusarium oxysporum: exploring the molecular arsenal of a vascular wilt fungus. Mol Plant Pathol. 2003;4(5):315-25. https://doi.org/10.1046/j.13643703.2003.00180.x.

38. Covey PA, Kuwitzky B, Hanson M, Webb KM. Multilocus analysis using putative fungal effectors to describe a population of Fusarium oxysporum from sugar beet. Phytopathology. 2014;104(8):886-96. https://doi.org/10. 1094/PHYTO-09-13-0248-R.

39. Meldrum RA, Fraser-Smith S, Tran-Nguyen LTT, Daly AM, Aitken EAB. Presence of putative pathogenicity genes in isolates of Fusarium oxysporum f. sp. cubense from Australia. Australas Plant Pathol. 2012;41(5):551-7. https://doi.org/10.1007/s13313-012-0122-X.

40. Niño-Sánchez J, Casado-Del Castillo V, Tello V, De Vega-Bartol JJ, Ramos B, Sukno SA, Díaz Mínguez JM. The FTF gene family regulates virulence and expression of SIX effectors in Fusarium oxysporum: the FTF genomic expansion of Fusarium oxysporum. Mol Plant Pathol. 2016;17(7):1124-39. https://doi.org/10.1111/mpp.12373.

41. Czislowski E, Fraser-Smith S, Zander M, O'Neill WT, Meldrum RA, TranNguyen LTT, Batley J, Aitken EAB. Investigation of the diversity of effector genes in the banana pathogen, Fusarium oxysporum f. sp. cubense, reveals evidence of horizontal gene transfer: effector genes in Fusarium oxysporum f. sp. cubense. Mol Plant Pathol. 2018;19(5):1155-71. https://doi.org/10.1111/ mpp.12594.

42. Fraser-Smith S, Czislowski E, Meldrum RA, Zander M, O'Neill W, Balali GR Aitken EAB. Sequence variation in the putative effector gene SIX8 facilitates molecular differentiation of Fusarium oxysporum f. sp. cubense. Plant Pathol. 2014;63(5):1044-52. https://doi.org/10.1111/ppa.12184.
43. Burkhardt A, Henry PM, Koike ST, Gordon TR, Martin F. Detection of Fusarium oxysporum f. sp. fragariae from infected strawberry plants. Plant Dis. 2019;103(5):1006-13. https://doi.org/10.1094/PDIS-08-18-1315-RE.

44. Kashiwa T, Inami K, Teraoka T, Komatsu K, Arie T. Detection of cabbage yellows fungus Fusarium oxysporum f. sp. conglutinans in soil by PCR and real-time PCR. J Gen Plant Pathol. 2016;82(5):240-7. https://doi.org/10.1007/ s10327-016-0668-5.

45. Kim H, Hwang S-M, Lee JH, Oh M, Han JW, Choi GJ. Specific PCR detection of Fusarium oxysporum f. sp. raphani: A causal agent of Fusarium wilt on radish plants. Lett Appl Microbiol. 2017;65(2):133-40. https://doi.org/10. 1111/lam.12761.

46. Stewart JE, Abdo Z, Dumroese RK, Klopfenstein NB, Kim M-S. Virulence of Fusarium oxysporum and F. commune to Douglas-fir (Pseudotsuga menziesii) seedlings: virulence of Fusarium oxysporum and F. commune. For Pathol. 2012:42(3):220-8. https://doi.org/10.1111/j.1439-0329.2011.00746.x.

47. van Dam P, de Sain M, ter Horst A, van der Gragt M, Rep M. Use of comparative genomics-based markers for discrimination of host specificity in Fusarium oxysporum. Appl Environ Microbiol. 2017;84(1):e01868-17. https://doi.org/10.1128/AEM.01868-17.

48. Dudley NS, James RL, Sniezko RA, Yeh A. Investigating koa wilt and dieback in Hawaii: pathogenicity of Fusarium species on Acacia koa seedlings. Native Plants J. 2007;8(3):259-66.

49. Cubero OF, Crespo A, Bridge P. DNA extraction and PCR amplification method suitable for fresh, herbarium-stored, lichenized, and other fungi. Plant Systematic Evolution. 1999;216:243-9.

50. Bankevich A, Nurk S, Antipov D, Gurevich AA, Dvorkin M, Kulikov AS, Lesin VM, Nikolenko SI, Pham S, Prjibelski AD, Pyshkin AV, Sirotkin AV, Vyahhi N, Tesler G, Alekseyev MA, Pevzner PA. SPAdes: A new genome assembly algorithm and its applications to single-cell sequencing. J Comput Biol. 2012;19(5):455-77. https://doi.org/10.1089/cmb.2012.0021.

51. Gurevich A, Saveliev V, Vyahhi N, Tesler G. QUAST: quality assessment tool for genome assemblies. Bioinformatics. 2013;29(8):1072-5. https://doi.org/10. 1093/bioinformatics/btt086.

52. Bertels F, Silander OK, Pachkov M, Rainey PB, van Nimwegen E. Automated reconstruction of whole-genome phylogenies from short-sequence reads. Mol Biol Evol. 2014;31(5):1077-88. https://doi.org/10.1093/molbev/msu088.

53. Guindon S, Gascuel O. A simple, fast, and accurate algorithm to estimate large phylogenies by maximum likelihood. Syst Biol. 2003;52(5):696-704. https://doi.org/10.1080/10635150390235520.

54. Langmead B, Salzberg SL. Fast gapped-read alignment with bowtie 2. Nat Methods. 2012;9(4):357-9. https://doi.org/10.1038/nmeth.1923.

55. Tavaré S. In: Miura RM, editor. Providence, Rl: Amer math Soc Some probabilistic and statistical problems in the analysis of DNA sequences. Some mathematical questions in biology - DNA sequence analysis; 1986. p. 57-86.

56. Pritchard L, Glover RH, Humphris S, Elphinstone JG, Toth IK. Genomics and taxonomy in diagnostics for food security: soft-rotting enterobacterial plant pathogens. Anal Methods. 2016;8(1):12-24. https://doi.org/10.1039/ C5AY02550H.

57. Fabijanić M, Vlahoviček K. Big data, evolution, and Metagenomes: predicting disease from gut microbiota codon usage profiles. In: Carugo O, Eisenhaber $F$, editors. Data mining techniques for the life sciences. Methods in molecular biology, 1415. New York, NY: Humana press; 2016. https://doi.org/ 10.1007/978-1-4939-3572-7_26.

58. Core Team R. R: A language and environment for statistical computing. In: R Foundation for statistical computing. Vienna: Austria. URL; 2019. https:// www.R-project.org/.

59. Ellinghaus, D., Kurtz, S., \& Willhoef, U. (2008). LTRharvest, an efficient and flexible software for de novo detection of LTR retrotransposons. 9(1), 18.

60. Smit, A. F. A., Hubley, R., \& Green, P. (2013-2015). RepeatMasker Open-4.0. http://www.repeatmasker.org.

61. Wyka SA. TransposableELMT - wrapper script to create a comprehensive repeat library for newly sequenced organisms. (version v1.0.0). Zenodo; 2019. https://doi.org/10.5281/zenodo.3469661.

62. Bushnell, B. (n.d.). BBMap—Sourceforge.net/projects/bbmap/.

63. Darling AE, Mau B, Perna NT. progressiveMauve: multiple genome alignment with gene gain, loss and rearrangement. PLoS ONE. 2010;5(6): e11147. https://doi.org/10.1371/journal.pone.0011147.

64. Kearse M, Moir R, Wilson A, Stones-Havas S, Cheung M, Sturrock S, Buxton S, Cooper A, Markowitz S, Duran C, Thierer T, Ashton B, Meintjes $P$, Drummond A. Geneious basic: an integrated and extendable desktop software platform for the organization and analysis 
of sequence data. Bioinformatics. 2012;28(12):1647-9. https://doi.org/10. 1093/bioinformatics/bts199.

65. Garrsion, E., \& Marth, G. (2012). Haplotype-based variant detection from short-read sequencing. https://doi.org/arXiv preprint arXiv:1207. 3907 [q-bio.GN].

66. Soderlund C, Bomhoff M, Nelson WM. SyMAP v3.4: A turnkey synteny system with application to plant genomes. Nucleic Acids Res. 2011;39(10): e68. https://doi.org/10.1093/nar/gkr123.

67. Cantarel BL, Korf I, Robb SMC, Parra G, Ross E, Moore B, Holt C, Sanchez Alvarado A, Yandell M. MAKER: an easy-to-use annotation pipeline designed for emerging model organism genomes. Genome Res. 2007;18(1):188-96. https://doi.org/10.1101/gr.6743907.

68. Smit, A. F. A., \& Hubley, R. (2008-2015). RepeatModeler Open 1.0. http:// repeatmodeler.org.

69. Ter-Hovhannisyan V, Lomsadze A, Chernoff YO, Borodovsky M. Gene prediction in novel fungal genomes using an ab initio algorithm with unsupervised training. Genome Res. 2008;18(12):1979-90. https://doi.org/10. 1101/gr.081612.108.

70. Zaharia, M., Bolosky, W. J., Curtis, K., Fox, A., Patterson, D., Shenker, S., Stoica, I., Karp, R. M., \& Sittler, T. (2011). Faster and more accurate sequence alignment with SNAP. http://arxiv.org/abs/1111.5572.

71. Keller O, Kollmar M, Stanke M, Waack S. A novel hybrid gene prediction method employing protein multiple sequence alignments. Bioinformatics. 2011;27(6):757-63. https://doi.org/10.1093/bioinformatics/btr010.

72. Xu L, Dong Z, Fang L, Luo Y, Wei Z, Guo H, Zhang G, Gu YQ, Coleman-Derr D, Xia Q, Wang Y. OrthoVenn2: A web server for whole-genome comparison and annotation of orthologous clusters across multiple species. Nucleic Acids Res. 2019;47(1):52-8. https://doi.org/10.1093/nar/gkz333.

73. Blin K, Shaw S, Steinke K, Villebro R, Ziemert N, Lee SY, Medema MH, Weber T. antiSMASH 5.0: updates to the secondary metabolite genome mining pipeline. Nucleic Acids Res. 2019;47(W1):W81-7. https:/doi.org/10.1093/nar/ gkz310.

74. Urban M, Cuzick A, Rutherford K, Irvine A, Pedro H, Pant R, Sadanadan V, Khamari L, Billal S, Mohanty S, Hammond-Kosack KE. PHI-base: A new interface and further additions for the multi-species pathogen-host interactions database. Nucleic Acids Res. 2017;45(D1):D604-10. https://doi. org/10.1093/nar/gkw1089.

75. Edgar RC. MUSCLE: multiple sequence alignment with high accuracy and high throughput. Nucleic Acids Res. 2004;32(5):1792-7. https://doi.org/10. 1093/nar/gkh340.

76. Untergasser A, Cutcutache I, Koressaar T, Ye J, Faircloth BC, Remm M, Rozen SG. Primer3-new capabilities and interfaces. Nucleic Acids Res. 2012;40(15): e115. https://doi.org/10.1093/nar/gks596.

77. Dudley NS, James RL, Cannon P, Yeh AK, Jones TC, Kaufmann MK. Developing resistant koa-early results, from disease survey to seedling resistance testing in Hawai'i. In: Proceedings of the 7th Meeting of IUFRO Working Party 7.03.04 Diseases and Insects in Forest Nurseries; 2009; Hilo, Hi; 2010. p. 39-47.

78. Komada $\mathrm{H}$. Development of a selective medium for quantitative isolation of Fusarium oxysporum from natural soil. Review Plant Protection Research. 1975;8:114-25

79. O'Donnell K, Sutton DA, Rinaldi MG, Magnon KC, Cox PA, Revankar SG Sanche S, Geiser DM, Juba JH, van Burik J-AH, Padhye AA, Anaissie EJ, Francesconi A, Walsh TJ, Robinson JS. Genetic diversity of human pathogenic members of the Fusarium oxysporum complex inferred from multilocus DNA sequence data and amplified fragment length polymorphism analyses: evidence for the recent dispersion of a geographically widespread clonal lineage and nosocomial origin. J Clin Microbiol. 2004:42:5109-20.

80. Liu YJ, Whelen S, Hall BD. Phylogenetic relationships among ascomycetes: evidence from an RNA polymerse II subunit. Mol Biol Evol. 1999:16(12): 1799-808.

81. Clement M, Posada D, Crandall K. TCS: a computer program to estimate gene genealogies, vol. 10; 2000. p. 1657-9.

\section{Publisher's Note}

Springer Nature remains neutral with regard to jurisdictional claims in published maps and institutional affiliations.

\section{Ready to submit your research? Choose BMC and benefit from:}

- fast, convenient online submission

- thorough peer review by experienced researchers in your field

- rapid publication on acceptance

- support for research data, including large and complex data types

- gold Open Access which fosters wider collaboration and increased citations

- maximum visibility for your research: over $100 \mathrm{M}$ website views per year

At BMC, research is always in progress.

Learn more biomedcentral.com/submissions 